\title{
Lukianos és Kallistratos mütárgyleírásai Szöveg és Hagyomány
}

\begin{abstract}
Lucian of Samosata's descriptions of works of art are invaluable for the studying of the Classical and post-Classical Greek sculpture. The Second Sophistic author does not only give accurate and detailed descriptions about Greek sculptures and paintings, but as a real connoisseur of art he also judges them from the perspective of aesthetics. In the first main part of my paper, I will focus on the characteristics of his descriptions by analyzing the nude figure of Aphrodite of Cnidus made by Praxiteles and the 'eclectic' portrait of Panthea. The aim of the second part of my paper is to present the essential features of Ekphraseis of the sophist Callistratus who lived in Late Antiquity (IV-Vth century AD). It has been disputed if Callistratus' work inspired by the rhetorical exercises has any art history values. This paper also raises the question how the tradition of both Lucian and Callistratus could influence the description of the sculpture 'Apollo Belvedere' included in Winckelmann's epoch-making Art History. ${ }^{1}$
\end{abstract}

Johann Joachim Winckelmann Az ókori müvészet története címü müve (1764) a maga korában paradigmaváltást hozott az antik müvészet történetében. ${ }^{2}$ Jóllehet a múvében foglalt megállapítások javarészt már túlhaladottakká

1 A publikáció elkészítését az MTA-SZTE Antikvitás és reneszánsz: források és recepció Kutatócsoport (TK2016-126) támogatta. Ezúton szeretnék köszönetet mondani Bencze Ágnesnek (PPKE) hasznos tanácsaiért és kitüntető bizalmáért, amelyek nagymértékben hozzájárultak a dolgozat létrejöttéhez és a téma továbbgondolásához.

2 Bővebben 1. Katherine HARLOE, Winckelmann and the Invention of Antiquity: History and Aesthetics in the Age of Altertumswissenschaft, Oxford, 2013; Alex POTTS, Flesh and the Ideal: Winckelmann and the Origins of Art History, Yale University Press, 1994. 
váltak, - pozitív hatásai mellett - bizonyos fokig máig kihatnak a görög müvészettörténetről alkotott képünkre. ${ }^{3}$ Winckelmann görög múvészettörténete rögzítette azokat a kulturális koordinátákat, amelyek - a klasszicizmus esztétikáján keresztül - a Kr. e. V-IV. századot mint klasszikust a müvelt Európa ízlésének abszolút mércéjévé tették. ${ }^{4}$

Winckelmann a görög müvészet egyfajta biológiai modelljét dolgozta ki, amely Pheidiasban és követőiben: a „magasztos stílusban” csúcsosodott ki, végső fázisát, a „hanyatlás korát” pedig szerinte a késő hellénisztikus és a római múvészetben érte el. ${ }^{5}$ Winckelmann szakított az antikváriusok gyakorlatával. Az idősebb Pliniustól ismert művész-kronológiát az antikvitás társadalom- és politikatörténetével, illetve személyes hangú új, stíluskritikai elemzéseivel egészítette ki, és közben tisztán esztétikai szempontokra, a stílusra, a müvészeti alkotás lényegére (Wesen) összpontosított. ${ }^{6}$ Személyes észrevételeivel dúsított, nem ritkán érzéki hangot megütő elemzései Niobé szobráról, a Laokoón-szoborcsoportról valamint a belvederei Apollónról, a Torzóról és Antinous szobrairól a korabeli olvasóban minden bizonnyal megdöbbenést kelthettek. ${ }^{7}$ Szövegei ezeken a pontokon hirtelen egyes szám harmadik személyből egyes szám első személybe, múlt időből jelen időbe váltanak át, ${ }^{8}$ olvasóját szinte aktív szemlélővé tesz: az elemzett szobor a logos útján megelevenedik. A hatás kedvéért a belvederei Apollón szobráról

\footnotetext{
${ }^{3}$ Winckelmann hatásáról 1. RADNÓTI Sándor: Jöjj és láss! A modern müvészetfogalom keletkezése, Winckelmann és a következmények, Bp., Atlantisz, 2010.

${ }^{4}$ A klasszikus fogalom új megközelítéséhez legújabban 1. Salvatore SETTIS, Supremely Original: Classical Art as Serial, Iterative, Portable = Serial/Portable Classic. Multiplying art in Greece and Rome, eds. Salvatore SeTtis, Anna ANGUissolA, Milan, Venice, Fondazione Prada, 2015, 5172; Uö, Futuro del classico, Torino, G. Einaudi, 2004, 44-50.

${ }^{5}$ Ranuccio Bianchi BANDINELLI, Luisa Franchi DELL'ORTO, Introduzione all'archeologia classica come storia dell'arte antica, Roma, Laterza, 2017,31 11-27.

6 Johann Joachim WincKelmanN, Geschichte Der Kunst Des Altertums, hrsg. Wilhelm SENFF, Weimar, Hermann Böhlaus Nachfolge, 1964, 123-179.

7 Erről részletesebben John Harry NORTH, Winckelmann's "Philosophy of Art." A Prelude to German Classicism, Newcastle, Cambridge Scholars Publishing, 2013, 97-149.

8 Elizabeth PRETTEJOHN, Beauty and Art 1750-2000, Oxford, Oxford University Press, 2006, 1819.
} 
beszélve Winckelmann az ovidiusi Átváltozásokból ismert ciprusi szobrász, Pygmalion álarcát is magára ölti: ${ }^{9}$

„Ez az Apollón olyannyira felülmúlja az isten minden más ábrázolását, mint Homéros Apollónja az őt követő költőkét.” - „Termete az emberiség fölé emelkedik [...]" - „Örök Tavasz öltözteti [...]” - hangzik Winckelmann elemzése, melyben részletesen lefesti az isten testének jellegzetességeit: ${ }^{10}$ „Úgy látszik, az istenek olajával kenték fel, s a Gráciák bájos pompával övezték fejét.” - „Lágyan omló haja úgy fonja körbe ezt az isteni fejet, mint szelíd légtől mozgatott gyengéd és tovafolyó kacskaringói." Apollón „szeme telve édességgel, mintha az őt ölelni vágyó múzsák közt volna.” "Az istenek atyjának valamennyi ránk maradt ábrázolásán, melyeket a művészet tisztel, nem kerül Zeusz oly közel az isteni költő elméjében megnyilatkozó nagysághoz, mint itt a fiú arculatában, és a többi isten egy-egy szép vonása miként Pandóránál - itt valami egésszé egyesül." Az elemző elméjét megbénítja a szobor fizikai közelsége: „Minden mást elfelejtek, ha a művészetnek ezt a csodálatos alkotását szemlélem, és fenséges tartást öltök magamra, hogy méltósággal tekintsek rá.” - „Szobrom - miként Pügmalión szépsége - megelevenedni és megmozdulni látszik." 11

Az eleven, lélegző és mozgó szobor az ókori ekphrasisok kedvelt témája volt már Homéros óta. ${ }^{12} \mathrm{Az}$ olvasók/hallgatók számára a leírt műalkotás hatásos képi megjelenítését a retorikától kölcsönzött enargeialevidentia ${ }^{13}$ és a sztoikus-szkeptikus elméletekből származó phantasia ${ }^{14}$ eszközrendszere biztosította. ${ }^{15}$ Egészen biztosra vehető, hogy Winckelmann alaposan ismerte az antik ekphrasis-hagyományt is. ${ }^{16}$

9 Paul BAROLSKY, Winckelmann, Ovid, and the Transformation of the Apollo Belvedere, Source, (2014) 2-4.

${ }^{10}$ Vö. még WiNCKELMANN, i. m., 152-163.

${ }^{11}$ Johann Joachim WincKeLMANN, A belvederei Apollón leírása = J. J. W., Müvészeti írások, ford. RAJNAI László, TíMÁR Árpád, Bp., Magyar Helikon, 2005,2 87-88.

12 Hom. Il. 18,468-617.

${ }^{13}$ Az enargeia-hoz (illustratio, evidentia) locus classicus: Quint. Inst. 6,2,26-36. Arist. Rh. 3,11,2.

${ }^{14}$ A phantasiai (visiones) vö. Quint. Inst. 6,2,29-30, Phil. V. A. 6,19. L. bővebben: Thomas D. BENEDIKTSON, Literature and the Visual Arts in Ancient Greece and Rome. Norman, Okla, University of Oklahoma Press, 2000, 162-188.

${ }^{15}$ Az ekphrasis áttekintéséhez a teljesség igénye nélkül:

Michael SQUIRE, Ecphrasis: Visual and Verbal Interactions in Ancient Greek and Latin Literature, 2015. www.oxfordhandbooks.com/view/10.1093/oxfordhb/9780199935390.001.0001/oxfordhb- 
A klasszika-archeológia atyjának egyik korai, úgynevezett párizsi kéziratának és margináliáinak vizsgálata kapcsán Katherina Harloe is felhívta a figyelmet az antik allúziók fontosságára. ${ }^{17} \mathrm{~A}$ kutató szerint a homérosi költemények mellett Pindaros, az Anthologia Graeca epigrammái, id. Philostratos $^{18}$ és a samosatai Lukianos müvészettel kapcsolatos múvei is Winckelmann keze ügyében lehetettek, amikor szoborleírásaihoz támpontot keresett, az antik források kiválasztásánál Franciscus Junius görög-római müvészetelméleteket szintetizáló munkája, a De pictura veterum (1637) is segítségére lehetett. ${ }^{19}$

A második szofisztika műtárgyleírásokkal foglalkozó szerzői, Lukianos, az idősebb és ifjabb Philostratos valamint Kallistratos a régi, „klasszikus” irodalmi formákhoz nyúltak vissza, amikor a görög irodalmi és képzőművészeti hagyomány felélesztésére tettek kísérletet a paideia

9780199935390-e-58 (Utoljára látogatva: 2018. 01.21.); Jaś ELSNER, Introduction: the Genres of Ekphrasis, Ramus, (31)2002, no. 1-2., 1-18; Ruth Webb, Ekphrasis Ancient and Modern: the Invention of a Genre, Word and image - Taylor and Francis, (15)1999, 7-18; Simon GOLDHILL, What Is Ekphrasis For?, Classical Philology, (102)2007, 1-19. Az iskolai használatra szánt progymnasmaták támpontot adnak a müfajjal kapcsolatos elméleti kérdésekhez: Theon Prog. 118,7; Hermog. Prog. 10,24-5; Nicol. Prog. 68,8.

16 Vö. Jaś ELSNER, Between mimesis and divine power: visuality in the Greco-Roman world = Visuality before and beyond the Renaissance. Seeing as others saw, ed. R. S. NELSON, Cambridge, Cambridge Univeristy Press, 2000, 20.

17 Winckelmann kéziratai 1798-ban kerültek Rómából Párizsba. A Bibliothéque Nationale-ban őrzött kéziratokat egy olasz könyvtáros katalogizálta a XVIII. század végén inkább tematikus, mint kronológiai sorrendben. A kéziratokban Winckelmann különböző ókori és modern szerzők művészetről szóló szövegeit kivonatolta, de két Apollón-vázlatot is tartlamaz: az egyik "Apollón," a másik "A belvederei Apollón leírása” címmel. A vázlatok egymással és a végleges, publikált szövegváltozattal is szoros kapcsolatban állnak, de kevés egyezést mutatnak a firenzei kézirattal. 1. részletesebben: Katherine HARLOE, Allusion and Ekphrasis in Winckelmann's Paris Description of the Apollo Belvedere, The Cambridge Classical Journal, (53)2007, 233-234.

$18 \mathrm{Az}$ id. Philostratos Eikonese kulcsfontosságú szerepet játszott az ókori falfestészetről alkotott kép kialakításban a reneszánsztól Winckelmann koráig, amikor Pompeii és Herculaneum feltárása is elkezdődtek. Winckelmann a párizsi kéziratában (71v) az olvasók figyelem felkeltésére használt "Nézd!" felszólító mód egyértelműen Philostratos hatását tükrözi. A „hora” imperativus tizenötször, „idou” tizenháromszor fordul elő az Eikonesben HARLOE, i. m., 238.

19 Uo., 236. 
szellemében. $^{20}$ A winckelmanni szoborleírások is az ókori minták nyomvonalán haladnak, voltaképp azt imitálták, ahogy az ókori olvasók vizualizálták a szobrokat. Noha Winckelmann az esztétikai véleményalkotás tudományos hitelességét kizárólag az autopsiához, a mütárggyal való személyes kapcsolathoz kötötte, ${ }^{21}$ az ókori szerzőknél ez a szemtől szembeni vizuális élmény nem feltétlen volt követelmény. Ebben a tekintetben kivétel a samosatai Lukianos. ${ }^{22}$ Vizsgálatainkat ezért célszerü az ő munkásságával kezdeni.

Mivel eredetileg szobrásznak készült, a múvészetek iránti fogékonyságát nem kizárólag szónoki előgyakorlatoknak, hanem nagybátyja szobrászműhelyében szerzett személyes tapasztalatainak (Luc. Som.), valamint itáliai és görög utazásai során szerzett vizuális élményeinek is köszönhette. ${ }^{23}$

Lukianos vagy prolaliai, azaz bevezető beszédek formájában kezdi az elbeszélést, vagy Winckelmannhoz hasonlóan olyan narratív szünetekkel szakítja meg, melyek a progymnasmák szabályainak megfelelően alkalmasak az ekphrasis témáinak kibontására, témái azonban nem hagyományos, történetíróktól vett progymnasma-témák: tájak, személyek, ünnepek vagy csaták, ${ }^{24}$ hanem a görög müvészet mestermüveit önti szavakba - méghozzá szakavatott és kritikus módon. Finom megfigyelései, a müalkotások pontos és aprólékos elemzése leírásait az antik képzőművészeti irodalom par excellence csúcspontjává tették. ${ }^{25}$ Lukianos nem csupán leírja a mütárgyat, hanem görög

${ }^{20}$ Vö. A képzőművészet és az ezüstkori epika kapcsolatához 1. NAGYILLÉS János, Fine Arts and Epic Poetry: Mimesis of Mimesis?, Acta Classica Univ. Scient. Debrecen, (48)2012, 91-116; Uő, Képzőmüvészet és epikus költészet: a mimésis mimésise? Irodalom és képzőmüvészet a korai

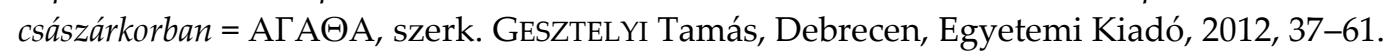

21 PRETTEJOHN, i. m., 21.

22 SZILÁGYI János György, A Görög müvészet világa. A görög képzömüvészetek archaikus és klasszikus korának írott forrásaiból, Bp., 1962, II, 226-227.

${ }^{23}$ Az életrajzi adatokhoz 1 . Valeria ANDÒ, Luciano critico d'arte, Palermo, Boccone del povero, 1975, 17-19.

24 Vö. Nicol. Prog. 68,11-12.

25 SZILÁGYI János György, Lukianos = Sz. J. Gy., Paradigmák: Tanulmányok Antik Irodalomról és Mitológiáról, Bp., Magvető, 1982, 141. Lukianos és a görög művészet kapcsolatához: LUCIANO di Samosata, Descrizioni di opere d'arte, a cura di Sonia MAFFEI, Torino, Einaudi, 1994, xviiixxv; Lukianos ekphrasisainak irodalmi párhuzamaihoz 1. a következő francia szövegkiadást: 
irodalmi és retorikai formákat mozgósít, hogy (újra)értelmezze és más megvilágításba helyezze a látottakat.

Írói teljesítményén túl azzal is kivívta az későbbi korok tiszteletét, hogy Plinius és Pausanias mellett segítségünkre van a görög müvészet rekonstruálásában: ${ }^{26}$ Myrón több római- és számos kis bronzmásolatból is ismert Diskobolosát például Lukianos pontos leírása segített azonosítani. ${ }^{27}$ Ebben Lukianos alteregója, Tychiadés magyarázza beszélgetőtársának a szobrok ikonográfiáját. A leírás - rövidsége ellenére - rendkívül érzékletes:

„A diszkoszdobóra gondolsz? - kérdeztem. - Aki épp dobásra készülő mozdulattal görnyed le a diszkoszt hozó lány felé fordulva, az egyik térdét finoman megroggyantva, nyilván azért, hogy majd a dobással felegyenesedjék"28 (Luc. Philops. 18, ford. Jánossy István).

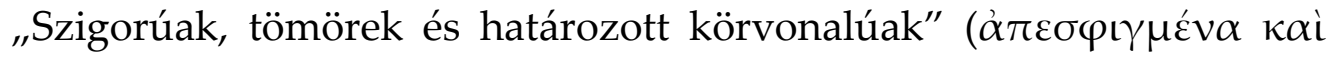

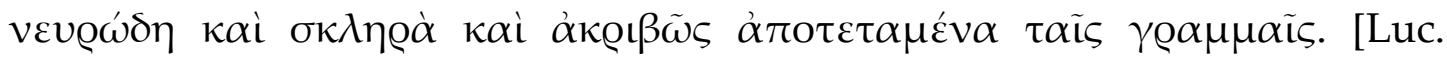
Rh.Pr. 9]) - Lukianos a korabeli esztétikai képzetek jegyében ezekkel a jelzőkkel illeti Kritios, Nésiotés és Hégésias alkotásait. A modern müvészettörténet azonban - az ókori értékítélettől elvonatkoztatva - már egészen más szemmel tekintett a koraklasszikus múvészeti irányzatra, a szigorú stílusra. ${ }^{29}$

LUCIEN de Samosate, Portrait du sophiste en amateur d'art, éd., trad. Sandrine DuBEL, Paris, Éd. Rue d'Ulm, 2014.

${ }^{26}$ Ehhez 1. bővebben Borg gondolatébresztő megjegyzéseit: Barbara BORG, Bilder zum Hören Bilder zum Sehen: Lukians Ekphraseis und die Rekonstruktion antiker Kunstwerke, Millennium, (1)2004, 25-57.

${ }^{27}$ L. Plin. HN 34,57; Quint. Inst. 2,13,20. Vö. Carol C. MATTUSCH, Naming the "Classical" Style= Charis: Essays in Honor of Sara A. Immerwahr, ed. Anne Proctor CHAPIN, Princeton, American School of Classical Studies at Athens, 2004, 282-283.

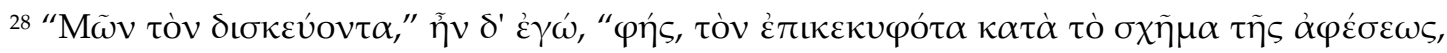

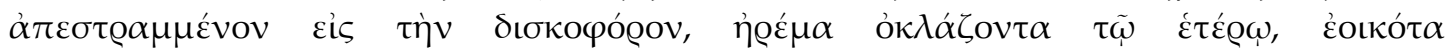

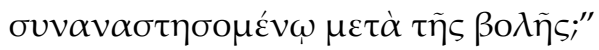

${ }^{29}$ Vö. Hégésias stílusához Quintilianus közhelyszerü jellemzése: duriora et Tuscanicis proxima (Quint. Inst. 12,10). A „szigorú stílus” modern nyelvekben használt terminusát először a német archeológiában a vázafestészetre használták: Ernst LANGLOTZ, Zur Zeitbestimmung der strengrotfigurigen Vasenmalerei und der gleichzeitigen Plastik, Leipzig, Beiträge, 1920 (non vidi). A szigorú stílus múvészetének tanulmányozásához l. Claude ROLLEY, La sculpture grecque, Paris, Picard éditeur, 1994, I, 318-396. 
Hasonlóan érzékletesek festményleírásai: ${ }^{30}$ tiszta és világos kompozíciójuk segített a reneszánsz korában életre kelteni a $\mathrm{Kr}$. e. V-IV. század görög mestereinek festményeit ${ }^{31}$ - mégis a szobrászat foglalkoztatta jobban. ${ }^{32}$ Végső soron az irodalmi elemzés eszköztárából vett analógiák, fogalmak (kanón, plasma, apotypósis) szobrászati leírásaiban kiválóan működnek: az alkotói munka során a nyersanyag úgy alakul és formálódik folyamatosan a szobrász keze alatt, mint az író elméjében a téma az invenció segítségével. ${ }^{33}$ A szobrászatot mégis megkülönbözteti más müvészeti formáktól az, hogy egy kultikus célokra készült szobor lehetőséget teremt a régmúlt tanulmányozásához is, amennyiben vallásos kontextusa miatt formavilága konzervatív és sokkal lassabban változik, így a múltat sokkal hübben őrzi. ${ }^{34}$

Lukianos neve alatt maradt fenn, és ha nem tőle, egy Kr. u. IV. századi lelkes utánzójától származik az Erótes Praxitelés knidosi Aphroditéjának érzéki leírása (Luc. Am. 11-17). ${ }^{35}$ A kutatás ezt a szobor fennmaradt

${ }^{30}$ Lukianos festményekről szóló prolaliai a Hippias, Dionysos, Héraklés és a Peri tou oikou (De domo) címet viselő írásai. A teremről c. müvében fiktív képelemzéseken keresztül a szerző saját módszertani elveit fogalmazza meg, melyeken keresztül a szerző nem csak a terem szépségére és annak dekorációs elemeire reflektál, hanem azt az elméleti problémát is felveti, hogy a szépségre adott válasz hogyan értelmezhető a nyelvben. Vö. ANDÓ, i. m., 19-24, SIMON Attila, Kövé dermesztő képek. Látvány, kép és erőszak Lukianos De domójában, Ókor: Folyóirat az antik kultúráról, 10(2011), 4. sz., 41-50.

31 Apellés festményének Rágalom c. lukianosi leírását (Luc. Cal. 2-5) használta Botticelli, Signorelli és Dürer. Botticelli festette meg az athéni Zeuxis Nősténykentaurját a lukianosi Zeuxis-leírás alapján (Luc. Zeux. 3-8), míg Aeitónnak a Nagy Sándor és Róxané nászát ábrázoló festményét - a Hérodotos vagy Aetiónt felhasználva (Luc. Herod. 4-6) - előbb Raffaello, majd Giovanni Antonio Bazzi keltetett életre: SZILÁGYI, i. m., 141; Donna Carol KURTZ, Reception of Classical Art, an Introduction, Oxford, Archaeopress, 2004, 35. Apellés reneszánsz recepciójához: Rudolph ALTROCCHI, The Calumny of Apelles in the Literature of the Quattrocento, PMLA, (36)1921, 454-491; Richard FÖRSTER, Die Verleumdung des Apelles in der Renaissance, Jahrbuch der Königlich Preußischen Kunstsammlungen, 8(1887), 29-56.

32 A klasszikus görög szobrok iránti nagyfokú érdeklődés más császárkori íroknál is nyomon követhető: Vö. Long. De Subl. 30,1; 36,3; 17,2; Philostr. V.A. 6,19; az Anthologia Graeca és Martialis epigrammái. További irodalomhoz l. James RoMM, Wax, Stone, and Promethean Clay: Lucian as Plastic Artist, Classical Antiquity, 9(1990), 75-76, 4. j.

${ }^{33}$ Hist. Conscr. 51.

${ }^{34}$ ROMM, i. m., 97, 60. j.

35 Vö. Plin. HN 34,20,8 és AP 16,159,160,162,163,166,168. 
másolatainak ismeretében hitelesnek fogadja el. Praxitelés szobra az első ruhátlanul ábrázolt nő a görög nagyszobrászatban. Így nincs mit csodálkozni azon, hogy a (pseudo)-lukianosi leírás a női test anatómiailag pontos megragadásán túl az agalmatophilia ${ }^{36}$ irodalmi toposzának jegyében összpontosít az istennő szépségére és erotikus vonásaira. ${ }^{37}$

A történetben a narrátor két látogatóval, Kallikratésszel és Chariklésszel érkezik az istennő knidosi templomához. A szobor a templom két oldaláról közelíthető meg, azok számára „akik hátulról is gondosan meg akarják szemlélni az istennőt, hogy semmi ne maradjon belőle megcsodálatlanul" (Luc. Am. 13). A belőle áradó erotika azonnal hatása alá vonja a templomba érkezőket:

Az istennő középen áll - gyönyörü mestermü, parosi márványból; kissé nyitott ajkán fenséges és szelíd mosoly játszik. Szépsége teljes rejtetlenségében jelenik meg, sehol sem fedi ruha, csak egyik kezével takarja el szinte alig észrevehető mozdulattal szemérmét. A kőfaragó müvészet ereje akkora volt, hogy a kő annyira rideg és kemény természete minden egyes testrész tulajdonságaihoz szépen alkalmazkodott [...] a szépség hirtelen látványától döbbenten álltunk meg. [...] Héraklésre, milyen gyönyörüen formált hát! milyen ölelésre

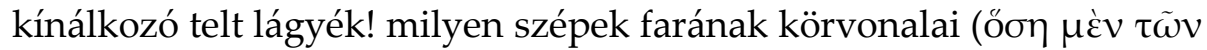
$\mu \varepsilon \tau \alpha \varphi \varrho \varepsilon ́ v \omega v \varepsilon \dot{v} \varrho v \theta \mu i ́ \alpha),{ }^{38}$ amelynek húsa nem tapad soványan a csontjaira, de túlságos kövérséggel sem dagad ki! s elmondhatatlan édességgel mosolyog a csípőjébe két oldalt bemélyedő két gödröcske! Comjának és lábfejéig egyenesen kinyújtott lábának arányai (@̣v $\theta \mu o$ í) kifogástalanok. Ganymédés lehet ilyen az égben, akinek kezétől töltve édesebb a nektár Zeusnak...! (Luc. Am. 13-14, ford. Vekerdy József)

A leírásban két „néző-típusra” lehet figyelmes az olvasó. A látogatókat kísérő templomszolga szemszögéből Aphrodité a vallási tisztelet tárgya marad.

\footnotetext{
${ }^{36}$ Luc. Am. 15. A szexuális érintkezés képzetét 1. E. Alc. 348-58; Ov. Met. 10,245-97; Plin. HN 36,21 .

37 Stijn Bussels, Epilogue: Erotic Reactions to Praxiteles' Cnidian Aphrodite $=$ The Animated Image: Roman Theory on Naturalism, Vividness and Divine Power, ed. S. B., 2012, 161-170.

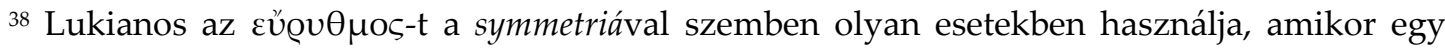
múalkotáson hangsúlyozni szeretné azoknak a testrészeknek a tökéletes arányát, amelyek eleganciát, finomságot és charist sugároznak ANDÓ, i. m., 68.
} 
Ezzel szemben a fiatal férfiak "profán" szemében az istennő egy gyönyörü és eleven nő. ${ }^{39}$ Hogy Praxitelésnek szándékában állt-e megjeleníteni a rendelkezésére álló eszközök bevetésével a valóságos hatást keltő érzékiséget, biztosra vehető. Az antik hagyomány szerint ugyanis a knidosi Aphrodité modellje Praxitelés szerelme, Phryné volt, ${ }^{40}$ másrészt éppen Praxitelés kora, a Kr. e. IV. század az, amikor a mimésis és a valóság-illúzió elméleti kérdéséről parázs vita folyt. ${ }^{41}$

A knidosi Aphrodité nem csak itt, hanem szélesebb kontextusba ágyazva máshol is feltünik a lukianosi corpusban. A szerző az Eikonesben az eikón és a logos agónjának Simónidés óta tartó hagyományra tekint vissza a festészet és költészet következő meghatározásában: “Ám Simónidés a festészetet hallgatag költészetként és a költészetet beszélő festészetként határozza meg." ${ }^{42}$ Ebben az enkómiasztikus betétben a két beszélgetőpartner, Lykinos és Polystratos Lucius Verus gyönyörü szeretőjét, Pantheát ${ }^{43}$ helyezi a középpontba. A második szofisztika szónokai a prózaírók tevékenységét gyakran vetik össze képszerüen is a szobrászok és festők alkotásaival. ${ }^{44} \mathrm{~A}$ szószobrász Lukianos sem tesz másként: a hölgy arcának megrajzolásakor a Kr. e. V-IV. század szobrászainak és festőinek remekműveiből válogat, ${ }^{45}$

${ }^{39}$ BORG, i. m., 52-54.

40 Ath. Deipnosophistae 590-591.

${ }^{41}$ Claude Rolley, La Sculpture Grecque, Paris, Picard, 1999, II, 257-267; SZILÁGYI János György, Az illúzió művészete = NÉMETH György, RITOÓK Zsigmond, SARKADY János, SZILÁGYI János György, Görög müvelődéstörténet, Bp., 2006, 605-607.

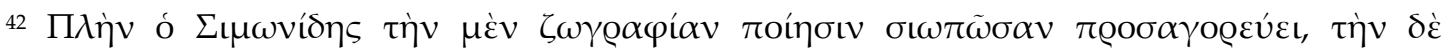

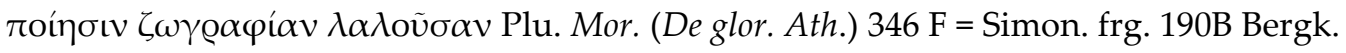

${ }^{43}$ Panthea irodalmi előképéhez: X. Cyr. 5,1.

${ }^{44}$ A művészek közötti versengés a Hérodotos vagy Aetiónban szintén kimutatható: Lukianos itt a történetírók és festők eredményeit teszi mérlegre. Ez az agónisztikus személet a császárkori

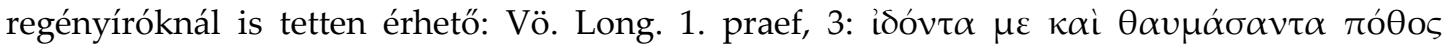

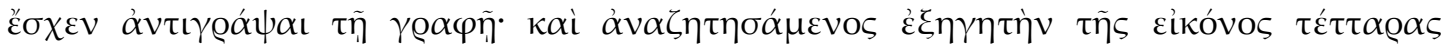

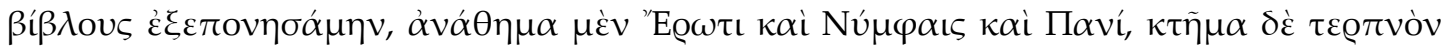

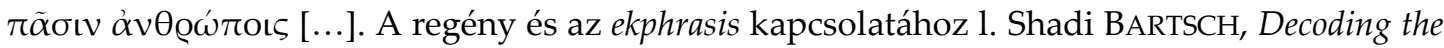
Ancient Novel: The Reader and the Role of Description in Heliodorus and Achilles Tatius, Princeton, Princeton University Press, 1989, 3-39.

45 Vö. Az irodalmi minták utánázának problémájához a figurális szobrászatból hoz példát a Rhetorica ad Herennium (Auct. Her. 4,9): Chares ab Lysippo statuas facere non isto modo didicit, ut Lysippus caput ostenderet Myronium, brachia Praxitelae, pectus Polycletium, sed omnia coram magistrum facientem videbat, ceterorum opera vel sua sponte poterat considerare. LUCIANO, i. m., liii. 
másképpen megfogalmazva: a "klasszikus" müvészet teljes kánonját olvasztja egybe a logos vegyítőedényében. A színek leírásához chrómatikus regiszter

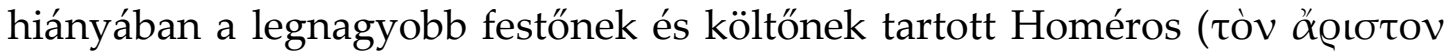

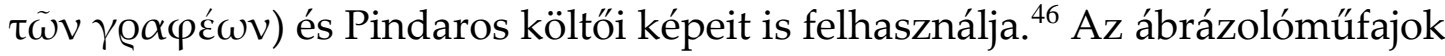
szokásos sorrendje itt megfordulni látszik. A szemünk előtt egy eleven nő verbális képpé, eikónná válik, a különféle képzőművészeti formák univerzális nyelvi kóddá transzformálódnak:

Nézd meg a képmást, miközben készül! A knidoszi szobornak csak a fejét vesszük át, a többi részére - mivel meztelen - nem lesz szükségünk. Ami a haját, homlokát és szépívü szemöldökét illeti, az maradjon úgy, ahogyan Praxitelész megformálta. Vágyódó, vidám és kedves tekintete szintén Praxitelész ízlését őrizze. Állát és arcának minden szemből látható részét Alkamenész szobráról vesszük, karja,

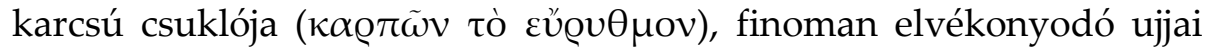
szintén a kerti Aphroditétól származzanak; de az arc kontúrjait, a friss orcákat, az arányos orrot Pheidiasz Lémniájáról mintázzuk, és az ő Amazonjáé lesznek összecsukott ajkai és nyaka. Kalamisz Szószandrája ékesítse szeméremmel, mosolya is tűnődő és alig észrevehető, mint az övé. Jól szabott, egyszerü ruháját is a Szószandrától kölcsönözzük azzal az eltéréssel, hogy fejét nem fedi fátyol. Életkorára, akármi is a valóság, a Knidoszi Aphroditét fogadjuk el mérvadónak, ebben is Praxitelész legyen a mérték. (Luc. Im. 6, ford. Bollók János)

Mint a szöveghelyből egyértelműen kiviláglik, Lukianos számára a klasszikus kori szobrászat nagyon is ismerős terep, a szerző a müvészetkritika technikai szókincsének professzionális ismerője. ${ }^{47} \mathrm{~A}$ pheidiasi művészetből az Athéna

\footnotetext{
${ }^{46}$ BORG, i. m., 49; Simon GOLDHILL, The erotic eye: visual stimulation and cultural conflict = Being Greek Under Rome: Cultural Identity, the Second Sophistic and the Development of Empire, ed. Simon GoldhILL, Cambridge, Cambridge University Press, 2001, 187-193; Maria CisTARO, Sotto Il Velo Di Pantea: Imagines e Pro Imaginibus Di Luciano, Messina, Dipartimento di scienze dell'antichità, 2009; SIMON Attila, Lukianosz, a szószobrász, Alföld, 64(2013), 3. sz., 55-63. A polikrómia szemszögéből közelít a Panthea-portréhoz: Mark BRADLEY, The Importance of Colour on Ancient Marble Sculpture, Art History, (32)2009, no. 3., 437.

47 ANDÓ, i. m., 65-69. A Lukianos által használt müvészetkritikai terminológiák áttekintéséhez szöveghelyek megadásával 1. Pollitt gyüjtését: Jerome J. POLLITT, The Ancient
} 
Lémnia arcának kontúrvezetését ( viszonyított arányát (@̃ĩv $\sigma u ́ \mu \mu \varepsilon \tau \varrho o v)$ és az Amazon összezárt ajkait

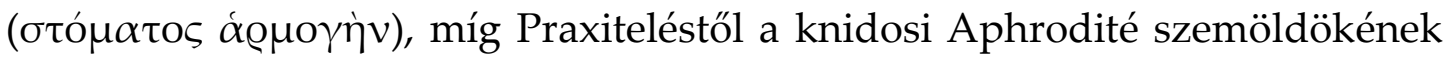

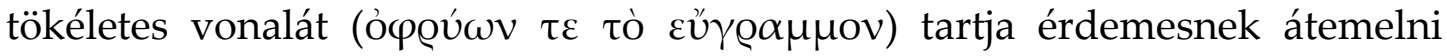
Panthea képmására. A végeredmény látványa, ami minden emberi szépségen túltesz, bénítólag hat, káprázatot és csodálatot vált ki belőlük: $\kappa \alpha i$ ő $\lambda \omega \varsigma \mu \varepsilon ́ \gamma \alpha$

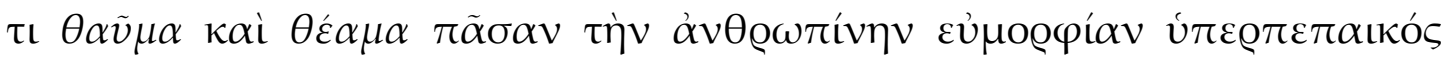
(Luc. Im. 9, kiemelés tőlem).

Panthea portréja amellett, hogy visszaad valamit számunkra az elveszett klasszikus görög művészet emlékeiből, fontos lehet abból a szempontból is, hogy a római császárkor görög müvészethez való viszonyulását tükrözi. A római felfogásban az elhunyt istennőkkel való összevetése, a szépsége és erkölcsiség hirdetése olyan témák, amelyek a Claudius és Nero-kori sírversekből, a funerális művészetből is ismertek. ${ }^{48}$

Panthea irodalmi portréjának formáló elemei a Kr. e. V. és IV. század szobrászatából merített stílusjegyek. A leírás a korabeli római ízlésnek megfelelő görög klasszicizáló müvészeti irányzat irodalmi lenyomatának is tekinthető. Az eklektikus módszer először a késő hellénizmus római szakaszában jelenik meg Rómában a dél-itáliai Pasitelés ${ }^{49}$ működése nyomán. ${ }^{50}$ Pasitelés és tanítványai különféle korú és stílusú görög szobrokat, azok formai megoldásait egyazon szoborban megújult tartalommal ötvözték. ${ }^{51}$ Ez az eklektikus módszer volt az Augustus, majd a HadrianusAntoninus kor múvészetének egyik irányzata is. ${ }^{52}$

Lukianosra egyrészt magára erre a müvészeti gyakorlatra reflektált, másrészt a császárkorban nagy népszerüségnek örvendő hellénisztikus kori

View of Greek Art: Criticism, History, and Terminology, New Haven, Yale University Press, 2006. 113-301.

48 LUCIANO, i. m., xlviii.

49 Pasiteléshez 1. Plin. HN 35,156; 36,39-40; Cic. Div. 1,36,79.

${ }^{50}$ LUCIANO, i. m., liii-liv; Froma I. ZEITLIN, Visions and revisions of Homer = Being Greek Under Rome: Cultural Identity, the Second Sophistic and the Development of Empire, ed. Simon GOLDHILL, Cambridge, Cambridge University Press, 2001, 233-234.

51 Vö. BENCZE Ágnes, Giccses vagy szellemes? Gondolatkísérlet egy "klasszicizáló római” szoborcsoport kapcsán, Ókor: Folyóirat az antik kultúráról, 13(2014), 2. sz., 62-72.

${ }^{52} \mathrm{Az}$ Augustus és a Hadrianus kor múvészetéhez: Bianchi R. BANDINELLI, Rome, the Centre of Power: Roman Art to Ad 200, London, Thames, Hudson, 1971, 177-279. 
szakírókra gondolhatott, amikor a Panthea-portré ürügyén a szó XIX. századi értelemében vett klasszikus kori ",szépségideálját" megalkotta. ${ }^{53}$

Lukianos kiterjedt utóéletének köszönhetően az Eikones nem maradt lelkes követők nélkül, ${ }^{54}$ olyannyira, hogy a Panthea-ekphrasis lebeghetett Winckelmann szeme előtt is, amikor a belvederei Apollón arcának lejegyzéséhez ehhez a "daraboló" technikához folyamodott. ${ }^{55}$ Lukianos hatására terjedtek el igazán és lettek divatosak a mütárgyleírások a császárkor későbbi századaiban. ${ }^{56} \mathrm{~A}$ szofista Kallistratos mütárgyleírásai szintén ehhez az ekphrasis-hagyományhoz csatlakoznak. Ekphraseis címen hagyományozódott munkája tizennégy képzőművészeti alkotás - tizenhárom szobor (agalmata) és egy festmény (eikón) - prózai leírását tartalmazza. Ezek név szerint a következők: Szatír, Bacchánsnő, Erós, Ind, Narkissos, Kairos, Orpheus, Dionysos, Memnón, Paian, Ifjú (éitheos), Kentaur, Médeia, Athamas.

A tizenhárom szoborból nyolc márványból, öt bronzból készült. Öt leírásból fény derül a szobrász nevére is: 1) a Bacchánsnőt megformáló Skopas; 2) egy Eróst, egy Dionysost és egy ifjút (éitheos) Praxitelés nevéhez kapcsol; 3) a Kairost pedig Lysippos nevéhez. A későklasszikus szobrászok megnevezésével Kallistratos éppúgy arra a Xenokratés által megkezdett müvészetkritikai hagyományra kíván reflektálni, mely a vizuális müvészetek későklasszikus korszakát emelte piedesztálra.

A szerzőről sem az ókori, sem a bizánci hagyomány nem tud többet. A szöveg szóhasználatából, mondatszerkesztéséből és stilisztikai jellegzetességeiből a filológusok arra a következtetésre jutottak, hogy

\footnotetext{
${ }^{53}$ Vö. Robert I. EdenBaum, Panthea: Lucian and Ideal Beauty, The Journal of Aesthetics and Art Criticism, 25(1966), 70.

54 Az Eikones inspirálta többek között Gian Giorgio Trissino Isabella d’Estének ajánlott irodalmi portréit (1524, Róma). LUCIANO, i. m., xlvi, 4. j. Erről részletesebben 1. Gian Giorgio TRISSINO, I ritratti, Roma, Ludovico degli Arrighi, 1524. Lukianos reneszánsz utóélethez: Keith C. SIDWELL, Lucian of Samosata in the Italian Quattrocento, University of Cambridge, 1974. 55 HARlOE, i. m., 243. L. még Agamemnón különféle istenekből összeválogatott portréját:

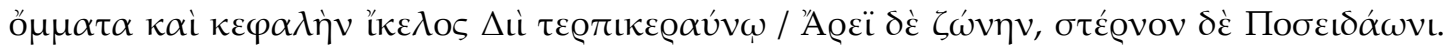
Hom. Il. 2, 478-79; ZEITLIN, i. m., 234.

56 Vö. Wolfgang BRASSAT, Michael SQUIRE, Die Gattung Der Ekphrasis = Handbuch Rhetorik Der Bildenden Künste, ed. W. B., Berlin, Boston, Walter de Gruyter GmbH, 2017, 63-88. Különösen bizánci recepciójához: Stratis PAPAOPANNOU, Michael Psellos: Rhetoric and Authorship in Byzantium, Cambridge, Cambridge University Press, 2016, 166-191.
} 
Kallistratos a késő antikvitás (Kr. u. IV-V. század?) egyik pogány szerzője. ${ }^{57}$ Altekamp elgondolása szerint a mütárgyleírások Konstantinápolyban születettek, ahol ebben az időben a görög szobrászat színe-java megtalálható volt nem titkolt politikai és ideológiai célokkal. ${ }^{58}$ Kallistratos a Philostratosok példáját követte abban, hogy egy egész művet szánt a képzőművészeti alkotások leírására. Ez egyúttal azt is jelzi, hogy az ekphrasis a késő antikvitásra önálló müfajjá terebélyesedett. ${ }^{59}$

Kallistratos nem bocsát szövegei elé módszertani bevezető prooimiont: ${ }^{60}$ éppen ezért az sem zárható ki, hogy Kallistratos múve töredékes formában maradt ránk. A töredékesség mellett szól az is, hogy az ekphrasisok utolsó darabja a figurális szobrászat világából a festészetébe vezeti át olvasóját, az egyetlen, Athamast ábrázoló eikón - a tizenhárom szoborleírás után valóban az esetleges szerkesztésben megnyilvánuló befejezetlenség érzetét keltheti. ${ }^{61}$

${ }^{57}$ Vö. Philostratus, CAllistratus, Philostrati Minoris Imagines Et Callistrati Descriptiones, eds. Karl SCHENKL, Emil REISCH, Lipsiae, In Aedibus B.G. Teubneri, 1902, XXIIf. A szofista müködésére számos datálási javaslat született a Kr. e. IV. századtól egészen a $\mathrm{Kr}$. u. V. századig bezárólag. Ehhez 1. Balbina BÄBLER, Heinz-Günther NESSELRATH, Ars Et Verba: Die Kunstbeschreibungen Des Kallistratos, Leipzig, Saur, 2006, 1-3. Kevésbé megalapozottnak tünik Antonio Corso elmélete, ami alapján Kallistratost a Severus-kori Athén kulturális közegébe

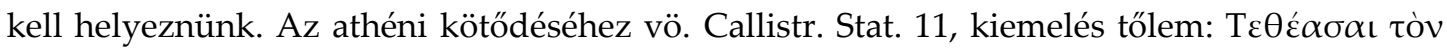

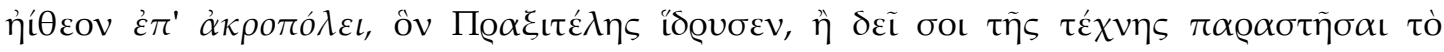
$\pi \varrho \tilde{\alpha} \gamma \mu \alpha$; „Láttad az ifjú szobrát az Akropolison, amit Praxitelés emelt, vagy szemed elé kell tárnom ezt a müalkotást?" L. részletesen: Antonio CORSO, Attitudes to the Visual Arts of Classical Greece in Late Antiquity, Eulimene, 2(2001), 17-23.

58 Stefan AlteKAmP, Zu den Statuenbeschreibungen des Kallistratos, Boreas, (11)1988, 82, 95. Cyril Mango, Michael VICKERS, E. D. Francis, The Palace of Lausus at Constantinople and Its Collection of Ancient Statues, Journal of the History of Collections, (4)1992, 89-92.

${ }^{59}$ Pollitt szerint az ekphrasist a Kr. u. III. század végig nem is alkalmazták mütárgyak leírására Jerome J. POLLITT, i. m., 87, 2. j. A Kr. u. V. században múködő myrai Nikolaos emelte be az ekphrasisok lehetésges témái közé a szobrokat és festményeket (Nicol. Prog. 69). Ebből a korszakból még a kopt Christodóros említésre méltó, aki Konstantinápolyban a Zeuxippos-

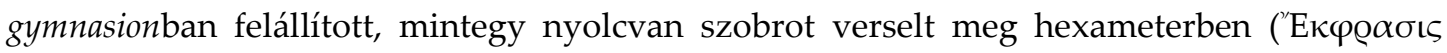

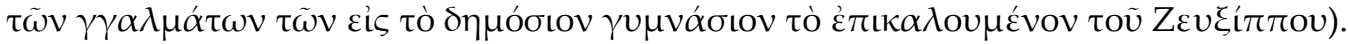

${ }^{60}$ Vö. Philostr. Im. 1. proem.; Philostr.Jun. Im. 861-863.

61 Philostratus, Callistratus, $i$. $m$., XLVII. 
A fennmaradt kéziratok időbeli eloszlásából arra következtethetünk, hogy a Kallistratos iránti érdeklődés sohasem lankadt. ${ }^{62} \mathrm{~A}$ mű görög nyelvü editio princepse 1503-ban jelent meg Velencében a Philostratosok Eikones címü képleírásaival és Lukianos néhány dialógusaival együtt. ${ }^{63}$ Első, francia nyelvü fordítását 1578-ban Blaise de Vigenère készítette. ${ }^{64}$ A fordítás a humanista körök mellett a szöveg szélesebb körü ismeretének terjedéséhez is hozzájárult. Franciscus Junius a De pictura veterum III. könyvében Kallistratos leírásaival illusztrálta, hogy hányféleképpen írható le egy szobor. ${ }^{65}$ Jóllehet Kallistratos a XVIII. század végéig hatással volt a szoborleírások müfajára, müvészek és kritikusok éppen Kallistratos megközelítését és szókincsét használták fel arra, hogy igazolják a kortárs szobrászat elsőbbségét az antik szobrokkal, de még Michelangelo szobraival szemben is. ${ }^{66}$ A szerző elsősorban filológiai - értékelését még a XX. század második felében is meghatározta az az elöítélet, ${ }^{67}$ hogy Lukianosszal vagy a két Philostratosszal összevetve, nem több tehetségtelen epigonnál. Kritizálták szépségideáljának felszínességét, művészetelméleti ismereteinek fogyatékosságait, ${ }^{68}$ az autopsia

${ }^{62}$ AlteKAMP, i. m., 80. A szöveghagyományhoz 1. még: Simone FOLLET, Brigitte MONDRAIN, La tradition manuscrite des Descriptions de Callistrate = Le Défi De L'art, Philostrate, Callistrate Et L'image Sophistique, éd. Michel COSTANTINI, Françoise GRAZIANI, Stéphane RoLET, Rennes, Presses universitaires de Rennes, 2006, 77-91.

63 AlteKAmp, i. m., 111-112. Kallistratos reneszánsz utóéletét is érinti Bencze Ágnes. L. BENCZE Ágnes, Michelangelo Bacchusának antik forrásaihoz, Ars Hungarica, (29)2013, 1-2. sz., 14-15.

64 AltekAmp, i. m., 113-115; Blaise de Vigenère, La Description de Callistrate. Traduction présentée par Françoise Graziani = Le Défi De L'art, Philostrate, Callistrate Et L'image Sophistique, éd. Michel COSTANTINI, Françoise GRAZIANI, Stéphane ROLET, Rennes, Presses universitaires de Rennes, 2006, 261-279; Blaise Vigenère, La Description De Callistrate De Quelques Statues Antiques Tant De Marbre Comme De Bronze (1602), éd. Aline MAGNIEN, Paris, La Bibliothèque, 2010 (non vidi).

65 AlteKamp, i. m., 116-117; Caroline ECK, Art, Agency and Living Presence: From the Animated Image to the Excessive Object, Boston, Walter de Gruyter, 2015, 39-40.

66 ECK, i. m., 40.

${ }^{67} \mathrm{Az}$ első nyomtatott kiadás megjelenésétől a XX. század második feléig Kallistratos olvasóközönségéröl 1. BÄBLER, NESSELRATH, i. m., 5.

68 Habár Kallistratos is ismer bizonyos müvészetelméleti szakkifejezéseket ( $\sigma 0 \mu \mu \varepsilon \tau$ ¿í $\alpha$,

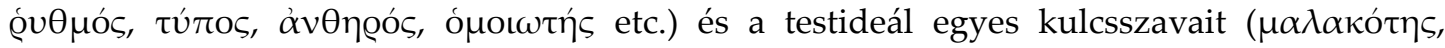

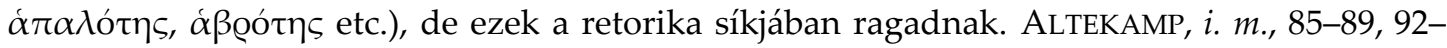
93. L. még ehhez POLLITT, i. m., 113-301. 
hiányát, és tulajdonképpen az egész Ekphraseisra úgy tekintettek, mint szoborleírások ürügyén született szónoklattani ujjgyakorlatokra. ${ }^{69}$

További adatok híján aligha válaszolható meg a Kallistratoskutatásnak az a kérdése, hogy szerzőnk, mintegy a művészeti emlékeket szemmel gyưjteni vágyó peregrinus, valóban járt-e a leírásaiban említett helyszíneken, vagy csupán saját olvasottságát és nyelvi kompetenciáit fitogtatva a szónokiskolák miliőjében alkotta meg az Ekphraseist. Tény viszont, hogy a szöveg egyes darabjaiból mégis olyan érzékletesség és plaszticitás sugárzik, hogy nem zárható ki, hogy valóban létező szobor alapján készültek. ${ }^{70}$ Ilyen leírást ad Praxitelésnek az egyéb forrásokból nem ismert Erós-szobráról:

[...] Nevetni készült, szeméből tüz és szelíd fény sugárzott; úgy tünt, hogy az érc aláveti magát az érzelmeknek, és könnyen hajlik a nevetés utánzására. Állt, jobb kezét homlokára hajlítva, míg másik kezével iját emeli a magasba, s tartásának egyensúlyát balra hajlítja el, mert bal csípőjét felemelte, hogy könnyed íveléssel megtörje az bronz merevségét. [...] (Callistr. Stat. 3)

Az azonosítására ugyan történtek kísérletek (l. a palatinusi Erós-torzó vagy a Farnese Erós példáját), ${ }^{71}$ de mind a mai napig nem jutott teljesen nyugvópontra a kérdés. Az irodalmi hagyományból tudjuk, hogy az athéni szobrásznak feltehetőleg több Erós-szobra is lehetett, ezek közül a legismertebb a thespiaii Erós. ${ }^{72}$ Tehát annak a kérdésnek a megválaszolása,

${ }^{69}$ BÄBLER, NESSELRATH, i. m., 12-15.

70 Ez idáig hat leírást sikerült azonosítani vagy kapcsolatba hozni a fennmaradt emlékanyaggal (Szatír, Bacchánsnő, Erós(?), Kairos, Dionysos, Memnón). A tizennegyedik leírásban az Athamas-festmény motívumait a vázafestészetével lehet kapcsolatba hozni. Négy további ekphrasis - Ind, Médeia, Narkissos és Orpheus - zsánerképek világával mutatnak egyezéseket. Éitheos, Paian és Kentaur leírásait nem lehet egyértleműen azonosítani a szobrászati emlékanyagban BÄBLER, NESSELRATH, i. m., 15; további részletekért 1. Uő-t az egyes leírásokhoz készített kimerítő régészeti kommentárt. A kentaur-leírás azonosításához 1. Karl LEHMANN, Kallistratos Meets a Centaur, American Journal of Archaeology, 61(1957), no. 2., 123-127.

71 BÄBLER, NESSELRATH, i. m., 43-49.

72 Paus. Periegeta 9,27; Ath. 13,590 D-591 C. 
hogy a Kallistratos által leírt Erós milyen volt Praxitelés müvészetének ismeretében, további vizsgálódások tárgya lehet.

Annál is fontosabb a kérdés: Kallistratos mennyiben tud - ha egyáltalán tud - az antik művészettörténet forrása lenni? Kallistratos szövegét "le sentiment de la chairként," a "test szenvedélyeként" határozták meg XVII. századi francia utánzói - nem alaptalanul: Kallistratos törekedett az élettel, a lélekkel és szenvedéllyel kapcsolatos tulajdonságok valósághü ábrázolására. Ez a törekvése gyakran mély pszichológiai tartalommal párosult. Kallistratos a bőr lágyságának és érzékiségének, a végtagok mozgásának vagy a vénákban folyó vérnek a nagyon is realisztikus képeit idézte fel olvasói előtt: ${ }^{73}$

(A szatír) kezében fuvola, hangjára elsőként szökken a magasba. Bár a fuvola játéka nem jutott el a füléhez és a hangszerből egy hang sem jött, a művészet a márványban mégis kifejezi azt a szenvedélyt, amit a fuvolán játszók átélnek. Láthattad megdagadni ereit, - mintha azok a lélegzésétól teltek volna meg, - tüdejéból a levegốt kifújni, hogy a furulyáját dalra fakassza. (Callistr. Stat. 1, kiemelés tőlem)

(Az ifjút) gyengédség lengte körül (habár a bronz valódi természete ezzel a finomsággal egyáltalán nem összeegyeztethető); az érc nem hajlékony, mégis rugalmasnak látszott... Lélegezni ugyan nem tudott, mégis úgy tünt, mintha levegőt venne. E tulajdonságait [...] a müvészet biztosította. Orcájának pírt adott: hihetetlen, de a bronzból pirospozsgás arcszint varázsolt. Fiatal fiúkra jellemző hamvasság áradt belőle. (Callistr. Stat. 11, kiemelés tőlem)

Mozdulni nem tudott (ti. a Bacchánsnő), mégis azt a benyomást keltette, hogy bacchusi őrületben tombol, aki átadja bensőjét a testébe hatoló istenségnek. Amikor arcát megpillantottunk, csak álltunk és szóhoz sem jutottunk, olyannyira kiütközött az érzés a valóságban érzelmektől mentes arcán. [...] A müvészet leírhatatlan eszköze által sugárzott belóle a szenvedély valamennyi jegye, melyet az órülettól megsebzett lélek csak mutathat. (Callistr. Stat. 2, kiemelés tőlem)

73 ECK, i. m., 39. 
Kallistratos felfogásában a szobrász a költőkhöz és prózaírókhoz hasonlóan az alkotás folyamatában az isteni ihletettség állapotába kerül. A szobrász ezáltal képes véghez vinni a lehetetlent: animát önteni az élettelen márványba. Hasonló történik a szobrot leíró szónok esetében: az enargeia alkalmazásával és a szavak helyes megformálásával segít az olvasónak megteremteni az élő jelenlét élményét. A leírás végén a Skopas és Démosthenés közötti paragoneval is igazolja a szobrászat és a retorika elmére gyakorolt egyenértékű hatását, amit Kallistratos hasonló szavakkal ír le, mint egykor Gorgias, amikor a meggyőzés erejét fejtette ki: ${ }^{74}$

Nem csak a költők és prózaírók müvészetét ihleti meg a nyelvüket megszálló Isten, hanem a képzőművészek kezét is isteni adományból szállja meg és vezeti az ihlet, hogy megszállottsággal eltelve hozzák létre alkotásaikat. Ez igaz volt Skopasra is, akit mintha ilyesféle isteni sugalmazás indított volna, hogy a benne lakozó istenségét szoborába is öntse. Miért ne fejtsem ki bővebben nektek e alkotás isteni ihletettségét? Olyan, parosi márványból készült bacchánsnő-szobor volt, mely hús-vér bacchánsnővé lényegült. A kő ugyan megőrizte saját természetét, mégis úgy látszott, túllépett az anyagban uralkodó törvényeken. Látványa igazi szoboré volt, de a múvészet az utánzást a valóságosságig fokozta. [...] Összegzésképpen: Skopas, bár élettelen szobrokat készített, a valóság mestere volt. Az (élettelen) testekbe a lélek csodáit képzelte bele. Miközben Démosthenés, aki szobrait beszédekben alkotta meg, szinte már láthatóvá tette a szavak formáját azáltal, hogy a múvészet varázsszerét az értelem és a lélek által létrehozott múvekkel vegyítette. (Callistr. Stat. 2)

A szobrokat elevenné varázsoló képesség irodalmi hagyományát Kallistratos jól ismerhette. Dionysos szoborleírásában Praxitelést a krétai Daidalosszal hozza összefüggésbe:

Ha hihetünk a Krétáról szóló mondáknak, Daidalosnak megvolt az a tehetsége, hogy a szobrokat a mozgás képességével ruházza fel és

\footnotetext{
${ }^{74}$ Vö. Gorg. Hel. 10 és 13; ECK, i. m., 38; Stijn BuSSELS, Creation and Impact of Art, Literature and speech: Callistratus' on the statue of a Bacchante = The Animated Image: Roman Theory on Naturalism, Vividness and Divine Power, ed. Stijn Bussels, Berlin, Akademie Verlag, 2012, 83108.
} 
rávegye az aranyat az emberi érzésekre. Azonban Praxitelés keze eleven szobrokat készített. (Callistr. Stat. 8)

Kallistratos synkrisise nem üres retorikai fogás. Aristotelés szerint „Daidalos a fából készült Aphrodité-szobrot úgy hozta mozgásba, hogy megtöltötte higannyal" (Ford. Steiger Kornél) (Arist. de An. 406b) ${ }^{75}$ Aristotelés elgondolása szerint Daidalosnak van valami trükkje: egy mechanizmus, valami (titkos) hozzávaló, amely a tárgyakat ugyan mozgásra bírja, ám ez nem terjed ki a szobrászat területére. Kallistratos ugyanakkor azt írja, hogy Praxitelés „élő szobrokat készített” és mestere annak, hogyan kell életet lehelni a bronzba. Tehát Kallistratos felfogásában Praxitelés sokkal közelebb van az élet utánzásához, mint a daidalosi müvészet: ${ }^{76}$

Volt egy liget, ahol egy ifjúként ábrázolt Dionysos-szobor állt, oly lágy volt, hogy a bronz valódi hús látszatát keltette. Teste olyan puha és könnyed, mintha a szobor a bronz helyett más anyagból készült volna. A szobor ércből készült, mégis elpirult. Noha élettelen volt, mégis törekedett az elevenség látszatára. Ha a szobrot megérintenéd, engedne ujjbegyednek. A bronz tömör és kemény volt, de a müvészet az ércet annyira megpuhította, hogy a kéz érintése is nyomot hagy rajta. Ez a Dionysos élete virágában volt, teli finomsággal, vágytól olvadozó, pontosan olyan, akit Euripidés a Bacchánsnökben ${ }^{77}$ megformált és szemünk elé állított. (Callistr. Stat. 8)

Praxitelés szobrainak kallistratosi leírásai sem mentesek a pathé-tól és az

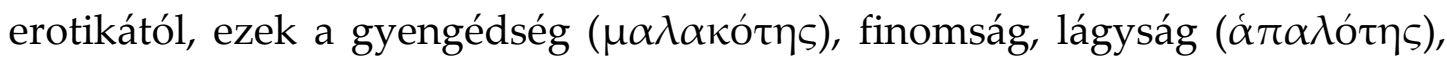
az érintés érzéki vágyának verbális képei. Ha beszélhetünk kallistratosi

\footnotetext{
75 A Politikában arról beszél, hogy „ha minden szerszám parancsra vagy a maga jószántából el tudná végezni munkáját, mint az Daidalosz készítményeiről vagy Héphaisztosz háromlábú székeiről beszélik, melyek a költő szavai szerint maguktól járnak az istenek tanácsába" (Arist. Pol. 1,4) (Ford. Szabó Miklós). Jackie PIGEAUD, Note sull'ekphrasis in Filostrato, Luciano e Callistrato $=$ Ekphrasis. Estetica. Studi e ricerche, a cura di Silvio MARINO, Alessandro STAVRU, 2013, 158 .

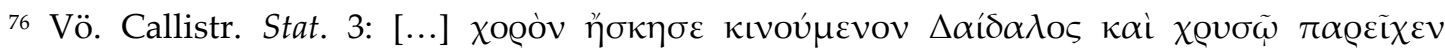
$\alpha i \sigma \theta \eta ́ \sigma \varepsilon \iota \varsigma,[\ldots], \ldots[. .$.$] Daidalos mozgó táncosok karát munkálta meg, és érzést öntött az$ aranyba [...]."

77 Vö. E. Ba. 322-326.
} 
szépségideálról, azt az Erós-Dionysost jellemző férfias jegyek uralják. ${ }^{78}$ Része a hajviselet, életkor tekintetében a fiatalkori sajátosságok (pais, efébos, éitheos). Ahogy a Lukianos neve alatt fennmaradt Erótesben, úgy Kallistratosnál is az látszik körvonalazódni, hogy a késő ókori szofista az érzéki erotika képeit verbalizálta és társította Praxitelés múvészetéhez. ${ }^{79}$

Előre bocsájtva az összegzést: a vizsgált szerzőket világosan összeköti az a hagyomány, amely a prózai ekphrasis-irodalmat tartalmi és formai szempontból meghatározza. Winckelmann a Kr. e. V-IV. századi szobrászatról vallott esztétikai értékítélete egybeesni látszik Lukianoséval. A samosatai szerző ekphrasis-betéteit a német archeológus jól ismerte kiváltképp a Panthea képmásáról szóló beszámolót is.

Ami Kallistratos ekphrasis-füzérét illeti, a főként későklasszikus és hellénisztikus kori szoborleírásokat taglaló mű a késő antikvitás egyfajta üzeneteként is értelmezhető. Kallistratos, aki a második szofisztika és pogány értelmiségi körök (pepaideuomenoi) képviselője volt, a maga korában szintén fontosnak érezte összegezni, mit érdemes tudni és ismerni a későklasszikus kori görög mesterek: Skopas, Praxitelés és Lysippos müvészetéről. A hagyomány ezt a sokszínü - mondhatni eklektikus - kallistratosi „művészettörténetet” Lukianos és Philostratosok műveivel bővítette ki. Ezek

\footnotetext{
78 ALTEKAMP, i. m., 92, 125.

${ }^{79}$ Hogy az ókori szobrok képesek a vágyak, a szenvedélyek közvetítésre, újabban jól láttatja André Aciman regénye alapján készült Call me by your name filmes adaptációja is, amely lépten-nyomon az antikvitás irodalmára és vizuális múvészetére utal. Az olaszországi helyszín a pásztori költészet érintetlen világát idézi fel, amely ideális terepet kínál a homoszexuális szerelem kibontakozásához is. A nyitójelentben feltünő ókori büsztök és torzók montázsszerüen egymásba fonódó képei rögtön tudatosítják a nézőben, az ókori szobrok kulcsfontosságúak lesznek a filmben. Hogy a szobrok szenvedélyeket gerjesztő aspektusait megértsék, egy klasszika-archeológus is a segítségükre van. A két fiatal férfi, Elio és Oliver egymásra találásban éppen egy, a Garda-tóból kihalászott praxitelési bronz hellénisztikus kori torzója jelenti a fordulópontot. Ebben a jelenetben a praxitelési efébos előkerülésével oldódnak az Elio és Oliver között kezdettől fogva fennálló feszültségek, tompulnak az őket mardosó bizonytalanságok. Megbékélésüket tréfásan a szobor bronzkarjának megrázásával „hitelesítik,” így Praxitelés mezítelen szobra szó szerint összekapcsolja a két fiatalembert és elgördíti érzelmeik előtt az utolsó akadályokat is.

Vö. https://antiquipop.hypotheses.org/antiquipop-english/3264eng

(Utoljára látogatva: 2018.02.03.).
} 
a szerzők először Bizáncban, majd a XVI. századi Itáliában találták rá a görög müvészetre fogékony olvasóközönségükre.

Kallistratos negatív megítélésében a német archeológus erőteljes véleménye szintén szerepet játszott: „Ez a silány szofista” - ahogy Kallistratost nevezi - „akár tízszer több szobrot is leírhatott volna, anélkül, hogy szemtől-szembe egyet is látott volna." 80 Tehát Winckelmann az autopsia felől közelített a késő antik szerzőhöz, tette ezt úgy, hogy a görög művészet csúcspontját jelentő pheidiasi művészetről ő maga is csak az antik forrásokból alkotott képet.

A kutatásban ez idáig kevés figyelmet kapott az a kérdés, hogy a görög ekphrasis-irodalom legnagyobb képviselői mellett Kallistratos stílusa és gondolatvilága mennyiben formálta Winckelmann szoborleírásait. Az a megállapítás, hogy a két szerzőnek általunk bemutatott szöveghelyei hasonló struktúra szerint épülnek fel, csak további szövegek bevonásával válik majd árnyaltabbá. Tény azonban, hogy Kallistratos és Winckelmann nagy hangsúlyt fektetnek az ifjúság virágával ékesített (férfi)test részletes és valósághü leírására: a hajviselet, ${ }^{81}$ az arc és a szemek verbális ábrázolására. A legfontosabb közös vonásukat abban kell látnunk, hogy mindkét szerző az érzelmek és a szenvedélyek szobrokban való megjelenítésére, a "le sentiment de la chair" megragadására törekedett. E fogalom alaposabb vizsgálata és összevetése az ókori müvészetelmélet fennmaradt szövegeivel Kallistratos ekphrasisának művészettörténeti értékére is jobban rávilágíthat.

80 Winckelmannt idézi: BÄBLER, NESSELRATH, i. m., 13-14.

81 Pl. 1. Dionysos (Callistr. Stat. 8) és Kairos (Callistr. Stat. 6) homlokára leomló dús hajfürtjeit. 